\title{
Perlindungan Hukum Masyarakat Terhadap Hak Atas Tanah Ber-Status Quo Di Pulau Galang
}

\author{
Lia Nuraini dan Dewi Haryanti \\ Universitas Maritim Raja Ali Haji Tanjungpinang \\ Jln. Raya Dompak Tanjungpinang \\ lianuraini23@umrah.ac.id; dewiharyanti@umrah.ac.id
}

Received: Received: 9 Oktober 2020; Accepted: 7 April 2021; Published: 2 Juni 2021

DOI: 10.20885/iustum.vol28.iss2.art4

\begin{abstract}
The land problem in Galang Island started from the unclear division of authority between the Batam Regional Authority and the Batam City Government as well as the land status of the Galang Island area which led to the status quo. Meanwhile, the community already has their rights, but is considered to be in an illegal location. The formulation of the problem in this research are first, how is the arrangement of the authority of land management rights in Galang Island? Second, how is the legal protection of the people who hold land rights with status quo in Galang Island area? This is a normative legal research with historical and conceptual approaches. Retrieval of legal material through literature study and document study with qualitative analysis techniques. The results of the study concluded that land management rights were given to the Chairman of the Batam Concession Agency (BP) who was ex officio led by the Mayor of Batam. Other land problems arose from the Decree of the Minister of Forestry Number 307 / Kpts-II / 1986, namely that the Galang area was included as a forest area and the determination of the status quo that had an impact on the community. The safeguards undertaken by the National Land Agency (BPN) are by not issuing land title certificates in Galang and for the land rights owned by the community if the Batam Concession Agency wants to acquire land in Galang which already has the status of land rights must compensate for the plants or existing buildings on the land.
\end{abstract}

Key Words: Land rihgts; legal protection; status quo

\section{Abstrak}

Permasalahan tanah di Pulau Galang diawali dari ketidakjelasan pembagian kewenangan antara Otorita Batam dengan Pemerintah Kota Batam serta status tanah wilayah Pulau Galang yang berujung pada status quo. Sementara masyarakat telah memiliki alas hak namun dianggap berada di lokasi illegal. Rumusan masalah dalam penelitian ini adalah, pertama, bagaimana pengaturan kewenangan hak pengelolaan tanah di Pulau Galang? Kedua, bagaimanakah perlindungan hukum masyarakat pemegang alas hak tanah yang ber-status quo di wilayah Pulau Galang? Penelitian ini merupakan penelitian hukum normatif dengan pendekatan historis dan konseptual. Pengambilan bahan hukum melalui studi pustaka dan studi dokumen dengan teknik analisis kualitatif. Hasil penelitian menyimpulkan bahwa hak pengelolaan tanah diberikan kepada Ketua Badan Pengusahaan (BP) Batam yang secara ex officio dipimpin oleh Wali Kota Batam. Permasalahan tanah lainnya muncul dari Keputusan Menteri Kehutanan Nomor 307/KptsII/1986 yaitu wilayah Galang termasuk sebagai kawasan hutan dan penetapan status quo yang berdampak kepada masyarakat. Upaya perlindungan yang dilakukan Badan Pertanahan Nasional (BPN) adalah dengan tidak menerbitkan sertifikat hak atas tanah di Galang dan terhadap alas hak yang dimiliki masyarakat apabila Badan Pengusahaan Batam ingin mengambil lahan di Galang yang sudah berstatus alas hak harus melakukan ganti kerugian terhadap tanaman-tanaman atau bangunan yang ada di atas tanah tersebut.

Kata-kata Kunci: Hak atas tanah; perlindungan hukum; status quo 


\section{Pendahuluan}

Pulau Galang berada di wilayah Kota Batam yang terbentuk berdasarkan Undang-Undang Nomor 53 Tahun 1999 yang ditetapkan pada 04 Oktober 1999. Kota Batam merupakan bagian dari Provinsi Kepulauan Riau, sedangkan Provinsi Kepulauan Riau merupakan daerah pemekaran dari Provinsi Riau 24 September 2002 dan menjadi provinsi ke 32 berdasarkan Undang-Undang Nomor 25 Tahun 2002.

Kota Batam merupakan daerah yang memiliki Hak Pengelolaan Lahan (HPL) langsung oleh Presiden berdasarkan Keputusan Presiden Nomor 41 Tahun 1973 tentang Daerah Industri Pulau Batam kepada sebuah Badan Otorita Pengelola yang di kemudian hari dialihkan kepada Badan Pengusahaan (selanjutnya disebut BP Batam). ${ }^{1}$

Seiring dengan semakin meningkatnya kegiatan usaha dan melihat terbatasnya kemampuan serta daya dukung yang tersedia di Daerah Industri Pulau Batam, maka Presiden menetapkan Keputusan Presiden Nomor 28 Tahun 1992 yang menambah Pulau Rempang dan Pulau Galang serta pulau-pulau kecil tertentu di sekitar Pulau Rempang dan Pulau Galang ke dalam Wilayah Lingkungan Kerja Daerah Industri Pulau Batam, sehingga aturan yang berlaku di Pulau Rempang dan Pulau Galang terutama dalam bidang pertanahan juga terikat dengan aturan Keputusan Presiden Nomor 41 Tahun 1973 dan Keputusan Menteri Dalam Negeri Nomor 43 Tahun 1977. Selanjutnya Pemerintah Pusat menetapkan Peraturan Pemerintah Nomor 46 Tahun 2007 juncto Peraturan Pemerintah Nomor 5 Tahun 2011 yang membentuk Kawasan Perdagangan Bebas dan Pelabuhan Bebas Batam yang wilayahnya meliputi Pulau Batam, Pulau Tonton, Pulau Setokok, Pulau Nipah, Pulau Rempang, Pulau Galang, Pulau Galang Baru, dan Pulau Janda Berias dan gugusannya. Peraturan Pemerintah tersebut juga mengubah kelembagaan Otorita Batam menjadi Badan Pengusahaan Kawasan Perdagangan Bebas dan Pelabuhan Bebas Batam (selanjutnya disebut BP Batam). ${ }^{2}$

\footnotetext{
${ }^{1}$ Ahmad Nurmandi, Menjaga Indonesia dari KEPRI (Peluang, Tantangan, \& Proil 19 Pulau Terdepan Indonesia di Kepulauan Riau), Badan Pengelola perbatasan Provinsi Kepulauan Riau, Tanjungpinang, 2012, hlm. 4.

2 "Sejarah Batam", https://jdih.batam.go.id/?page id=500, diakses pada tanggal 4 Januari 2021.
} 
Perubahan status Pulau Batam menjadi Kawasan Perdagangan Bebas dan Pelabuhan Bebas tersebut tidak mengubah status tanah yang hak pengelolaanya dimiliki oleh BP Batam. Sejak 1992 muncul Penetapan ber-status quo terhadap wilayah Galang. Berdasarkan Keputusan Presiden Nomor 28 Tahun 1992, Galang masuk wilayah kerja Otorita Batam (OB) yang saat ini menjadi BP Batam. Namun karena menyandang status quo dan ditetapkan menjadi hutan konservasi, lahan di sana belum bisa dialokasikan oleh BP Batam. Di dalam hutan konservasi itu juga terdapat hutan buru. Sesuai Surat Keputusan Menteri Kehutanan Nomor 307/Kpts-II/1986 pada 29 September 1986, luas hutan buru di Relang mencapai 16 ribu hektar. ${ }^{3}$

Permasalahan pengelolaan tanah di Pulau Batam termasuk di sini tanah di Pulau Rempang, Pulau Galang, Pulau Galang Baru, dan 39 pulau kecil lainnya berawal dari diundangkannya Undang-Undang Nomor 53 Tahun 1999 juncto Undang-Undang Nomor 13 Tahun 2000, sebagaimana dalam Pasal 21 ayat (1) menyatakan bahwa, "dengan terbentuknya Kota Batam sebagai daerah otonom Pemerintah Kota Batam dalam penyelenggaraan pemerintahan dan pembangunan didaerahnya mengikutsertakan Badan Otorita Batam". Ketentuan pasal tersebut menimbulkan permasalahan baik dari sisi BP Batam maupun Pemerintah Kota Batam sebab pembagian kewenangan di antara keduanya menjadi tidak jelas, termasuk didalamnya terkait kewenangan pengelolaan tanah. Lebih lanjut, ketentuan Pasal 21 ayat (3) menyebutkan bahwa, "hubungan kerja antara Pemerintah Kota Batam dan Badan Otorita Batam diatur lebih lanjut dengan peraturan pemerintah", hal ini memberikan kewajiban kepada pemerintah pusat untuk menetapkan peraturan di maksud. Namun, dalam perkembangannya, sampai saat ini aturan yang mengatur pembagian kewenangan tersebut belum juga ditetapkan. Ketidakjelasan pembagian kewenangan antara BP Batam dengan Pemerintah Kota Batam berdampak pada terhambatnya iklim investasi, khususnya dalam pemberian layanan pengelolaan lahan. ${ }^{4}$

\footnotetext{
3 “Kendala-Kendala Status Rempang-Galang", https://batampos.co.id/2018/ 03/22/ kendala-kendalastatus-rem pang-galang/, diakses pada tanggal 28 November 2019.

4 Nur Hadiyati, "Memahami Problematikan Hak Pengelolaan Tanah Kota Batam dalam Rangka Penetapan Batam Sebagai Kawasan Ekonomi Khusus", Jurnal Yurispruden, Volume 2 Nomor 1, Januari 2019, hlm. 61.
} 
Pada 2013 telah terjadi permasalahan terkait tumpang tindih status tanah di Kota Batam. Menteri Kehutanan menerbitkan Surat Keputusan Nomor SK. 463/Menhut-II/2013 yang menetapkan kawasan hutan lindung terhadap tanah di Pulau Batam yang merupakan Hak Pengelolaan BP Batam dan beberapa telah dilekatkan hak atas tanah oleh masyarakat. ${ }^{5}$ Dampak dari ditetapkannya Keputusan tersebut, menyebabkan sekitar 22.000 rumah dan 49 galangan kapal di Batam berada di lokasi illegal. Padahal sebelumnya, rumah dan galangan kapal tersebut telah mendapat izin resmi dari BP Batam. Permasalahan ini, tidak hanya menimbulkan ketidakpastian hukum dalam bidang pertanahan namun yang paling signifikan berdampak pada terhambatnya iklim investasi, terlebih lagi Batam merupakan Kawasan Perdagangan Bebas dan Pelabuhan Bebas yang diharapkan mampu memberikan sumbangan bagi perekonomian Negara. ${ }^{6}$

\section{Rumusan Masalah}

Berdasarkan latar belakang di atas, maka rumusan masalah dalam penelitian ini yaitu, pertama, bagaimana pengaturan kewenangan hak pengelolaan tanah di Pulau Galang? Kedua, bagaimana perlindungan hukum masyarakat pemegang alas hak tanah yang ber-status quo di wilayah Pulau Galang?

\section{Tujuan Penelitian}

Berdasarkan rumusan masalah di atas, maka tujuan penelitian ini yaitu untuk mengetahui, pertama, pengaturan kewenangan hak pengelolaan tanah di Kota Batam khususnya Pulau Galang. Kedua, konsep perlindungan hukum bagi masyarakat pemegang alas hak atas tanah yang ber-status quo di wilayah Pulau Galang.

\section{Metode Penelitian}

Jenis penelitian ini adalah penelitian hukum normatif dengan metode pendekatan historis dan pendekatan konseptual. Pendekatan historis digunakan untuk mengetahui kronologi pengaturan tanah di Pulau Galang yang berada dalam wilayah Kota Batam dan merupakan rangkaian pulau besar ketiga setelah

\footnotetext{
${ }^{5}$ Isdian Anggraeny, “Akibat Hukum Insinkronisasi Pengaturan Bidang Pertanahan di Kota Batam”, Jurnal Mahasiswa Fakultas Hukum Universitas Brawijaya, Malang, 2014, hlm. 4

${ }^{6}$ Ibid.
} 
Pulau Batam dan Pulang Rempang, sehingga menjadi tanah yang ber-status quo. Pendekatan konseptual digunakan untuk mengajukan konsep perlindungan hukum terhadap masyarakat Pulau Galang yang berada di wilayahh tanah yang ber-status quo. Sumber data penelitian ini adalah data sekunder yang meliputi bahan hukum primer, sekunder dan tersier. Pengumpulan data dilakukan melalui studi pustaka dengan mengkaji literatur yang berhubungan dengan permasalahan penelitian serta studi dokumen dengan mengkaji peraturan perundang-undangan yang berhubungan dengan permasalahan penelitian serta melakukan wawancara dengan narasumber sebagai data dukung untuk melakukan pembahasan atau analisa data. Teknik analisa data yang digunakan adalah analisis kualitatif berupa pemaparan, uraian, serta gambaran atas hasil penelitian.

\section{Hasil Penelitian dan Pembahasan}

\section{Gambaran Umum Pulau Galang}

Pada awalnya setelah Indonesia merdeka, Pulau Galang secara geografis berada dalam wilayah Tanjungpinang. ${ }^{7}$ Selanjutnya, berdasarkan Keputusan Presiden Nomor 28 Tahun 1992 maka Pulau Galang ditambahkan sebagai salah satu wilayah lingkungan kerja Daerah Industri Pulau Batam yang merupakan wilayah usaha Kawasan Berikat (Bonded Zone). ${ }^{8}$ Dengan demikian, jika membahas tentang Pulau Galang maka tidak terlepas dari Kota Batam sebagaimana dituangkan dalam Undang-Undang Nomor 53 Tahun 1999, dimana Kota Batam ditata dan ditetapkan menjadi wilayah yang meliputi delapan Kecamatan yaitu Kecamatan Batu Ampar, Kecamatan Nongsa, Kecamatan Galang, Kecamatan Sungai Beduk, Kecamatan Bulang, Kecamatan Belakang Padang, Kecamatan Sekupang, dan Kecamatan Lubuk Baja. ${ }^{9}$ Pesatnya perkembangan pembangunan

\footnotetext{
7 "Pulau Galang dari Masa ke Masa" https://kebudayaan.kemdikbud.go.id/bpnbkepri/pulau-galang-darimasa-ke-masa/, diakses tanggal 4 Maret 2021.

${ }^{8}$ Pengertian Kawasan Berikat (Bonded Zone) dapat dilihat dalam Pasal 1 Peraturan Pemerintah Nomor 22 Tahun 1986, dimana Kawasan Berikat ialah suatu kawasan dengan batas-batas tertentu di wilayah pabean Indonesia yang didalamnya diberlakukan ketentuan khusus di bidang pabean, yaitu terhadap barang yang dimasukkan dari luar daerah pabean, atau dari dalam daerah pabean Indonesia lainnya tanpa terlebih dahulum dikenakan pungutan bea, cukai dan/atau pungutan negara lainnya sampai barang tersebut dikeluarkan untuk tujuan impor, ekspor, atau re-ekspor.

9 Lihat Pasal Pasal 10 ayat (2) dan Pasal 11 ayat (1) Undang-Undang Nomor 53 Tahun 1999 tentang Pembentukan Kabupaten Pelalawan, Kabupaten Rokan Hulu, Kabupaten Rokan Hulu, Kabupaten Rokan Hilir, Kabupaten Siak, Kabupaten Karimun, Kabupaten Natuna, Kabupaten Kuantan Singingi, Dan Kota Batam.
} 
dan jumlah penduduk, maka terjadi pemekaran kecamatan di Kota Batam sebagaimana dituangkan dalam Peraturan Daerah Kota Batam Nomor 02 Tahun 2005 sehingga jumlah kecamatan di Kota Batam menjadi 12 kecamatan. ${ }^{10}$

Wilayah Kecamatan Galang sebelah Utara berbatasan dengan Bintan Utara (Kabupaten Bintan), sebelah Selatan berbatasan dengan Kecamatan Senayang (Kabupaten Lingga), sebelah Barat berbatasan dengan Kecamatan Bulang, dan sebelah Timur berbatasan dengan Kecamatan Tanjungpinang Kota (Kota Tanjungpinang). Luas wilayah perairan $1.667,72 \mathrm{~km}^{2}$ dan wilayah daratan mencapai 350,76 km². Untuk permukaan tanah di Kecamatan Galang datar dengan variasi bergelombang. ${ }^{11}$

Jumlah pulau dan luas kelurahan di Kecamatan Galang dapat dilihat dari tabel berikut. ${ }^{12}$

Tabel 1:

Jumlah Pulau dan Luas Kelurahan di Kecamatan Galang

\begin{tabular}{cllrc}
\hline No & Nama Kelurahan & Ibukota Kelurahan & Luas $\left(\mathrm{Km}^{2}\right)$ & Luas Pulau $\left(\mathrm{Km}^{2}\right)$ \\
\hline 1 & Pulau Abang & Pulau Abang & 28,61 & 53 \\
2 & Karas & Karas & 50,45 & 10 \\
3 & Sijantung & Sijantung & 39,62 & 12 \\
4 & Sembulang & Sembulang & 65,83 & 6 \\
5 & Rempang Cate & Rempang Cate & 91,52 & 6 \\
6 & Subang Mas & Subang Mas & 20,25 & 11 \\
7 & Galang Baru & Galang Baru & 50,29 & 20 \\
8 & Air Raja & Air Raja & 4,19 & 2 \\
& Galang & Sembulang & 350,76 & 120 \\
\hline
\end{tabular}

Sumber Data: Diolah dari Buku "Kecamatan Galang Dalam Angka", 2020

Berdasarkan Tabel 1 di atas, maka dapat dilihat bahwa Kecamatan Galang beribukota di Sembulang, memiliki delapan kelurahan dengan luas wilayah yaitu $350,76 \mathrm{~km} 2$ dan memiliki pulau sebanyak 120 pulau.

Jumlah penduduk penduduk di Kecamatan Galang dapat dilihat dari tabel berikut: 13

\footnotetext{
${ }^{10}$ Lihat Bab II Pasal 2 sampai dengan Pasal 13 Perda Kota Batam Nomor 02 Tahun 2005.

${ }^{11}$ Febry Utami beserta Tim, Kecamatan Galang Dalam Angka, BPS Kota Batam, Batam, 2020, hlm. 3

${ }^{12}$ Ibid., hlm. 5-6.

${ }^{13}$ Data diperoleh dari Kasi Pemerintahan Kecamatan Galang di Kantor Camat Galang pada 9 Juli 2020.
} 
Tabel 2:

Jumlah Penduduk berdasarkan KK dan Kelurahan Di Kecamatan Galang 2019

\begin{tabular}{clcc}
\hline No & Nama Kelurahan & Jumlah Penduduk & Jumlah Kk \\
\hline 1 & Sijantung & 1,799 & 545 \\
2 & Karas & 2,782 & 849 \\
3 & Sembulang & 2,801 & 872 \\
4 & Subang Mas & 869 & 265 \\
5 & Rempang Cate & 3,042 & 990 \\
6 & Air Raja & 645 & 189 \\
7 & Pulau Abang & 1,636 & 460 \\
8 & Galang Baru & 2.787 & 802 \\
\hline & Total & $\mathbf{1 7 . 0 4 6}$ & $\mathbf{5 . 1 7 4}$ \\
\hline
\end{tabular}

Sumber: Data Olahan Kantor Camat Galang, Tahun 2020

Berdasarkan Tabel 2 di atas, dapat dilihat bahwa jumlah penduduk di Kecamatan Galang sebanyak 17.046 jiwa yang terbagi dalam 5.714 Kepala Keluarga (KK) dengan jumlah penduduk terbanyak ada di Kelurahan Rempang Cate, sedangkan jumlah penduduk terkecil berada di Kelurahan Air Raja.

\section{Kewenangan Hak Pengelolaan Tanah di Pulau Galang}

Pengaturan tanah di wilayah Galang berdasarkan Keputusan Presiden Nomor 28 Tahun 1992 yaitu memasukkan Galang sebagai Wilayah Usaha Kawasan Berikat (Bonded Zone) sedangkan berdasarkan Surat Keputusan Menteri Kehutanan Nomor 307/Kpts-II/1986 pada 29 September 1986 wilayah Galang masuk sebagai kawasan hutan dan berdasarkan Surat Keputusan Nomor 29 Tahun 2002 tentang Pengendalian Tata Guna Lahan Rempang dan Galang, yang mengakibatkan kawasan tersebut menjadi ber-Status Quo. Badan Pengusahaan (BP) Batam sedang mengupayakan agar pemerintah pusat segera menyelesaikan status quo lahan di Galang. Tujuannya agar Galang bisa segera dimanfaatkan karena BP Batam telah memetakannya menjadi salah satu zona strategis Kawasan Ekonomi Khusus (KEK). ${ }^{14}$

Sebagaimana di ketahui bahwa pengelolaan tanah di Galang sama dengan wilayah lainnya di Batam yakni dengan pemberian Hak Pengelolaan. Seluruh Hak Pengeloaan baik masyarakat maupun perusahaan yang ada di Pulau Galang tersebut berupa alas hak yang dibuat oleh Camat setempat. Hal ini menimbulkan

14 "Pulau Galang dan Pulau Rempang Bakal Jadi Lokasi wisata” https://travel.tempo.co/read/1051777/pulaugalang-dan-pulau-rempang-bakal-jadi-lokasi-wisata/full\&view=ok, diakses tanggal 2 Februari 2021. 
polemik akibat lamanya ber-status quo yang ditetapkan di wilayah Galang tersebut sehingga akan sulit bagi BP Batam untuk mengubah wilayah tersebut menjadi Kawasan Ekonomi Khusus. Karena baik masyarakat maupun perusahaan yang ada disana diberikan hak oleh kepala desa sebelum 1992 untuk mengusahakan tanah/lahan yang ada di wilayah Galang. Terdapat banyak perkebunan dan peternakan serta beberapa perusahaan mengusakan lahan di wilayah Galang sebagai kawasan pariwisata dengan status alas hak. ${ }^{15}$

Meskipun masyarakat telah memiliki status alas hak terhadap tanahnya tetapi tidak dapat ditingkatkan dasar haknya tersebut untuk mendapatkan sertifikat hak atas tanah dari Badan Pertanahan (BPN). Peraturan perundangundangan mengatur terkait kewenangan, kewajiban serta larangan untuk berbuat sesuatu terhadap semua hak pengusaan atas tanahnya seperti Hak Milik sebagaimana dituangkan dalam Pasal 20 Undang-Undang Pokok Agraria (UUPA) yang mana memberikan wewenang kepada pemegang Hak Milik untuk menggunakan tanahnya tanpa batas waktu. Sementara untuk Hak Guna Usaha (HGU) sebagaimana diatur dalam Pasal 28 UUP mengatur jangka waktu penggunaan tanahnya. Begitu pua terkait Hak Guna Bangunan (HGB). Hak Tanggungan terhadap hak penguasaan atas tanah yang berisikan kewenangan bagi kreditor untuk berbuat sesuatu mengenai tanah yang dijadikan agunan. ${ }^{16}$

Berkaitan dengan hal tersebut di atas, maka dapat dilihat pendapat Budi Harsono bahwa terhadap kepastian hukum serta kepastian hak atas tanah menghendaki adanya: 1. Peraturan hukum pertanahan yang tertulis yang dilaksanakan dengan baik. 2. Diselenggarakannya pendaftaran tanah yang efektif dan efisien. Pemerintah melakukan kegiatan pendaftaran tanah dengan sistem yang sudah melembaga sebagaimana yang dilakukan dalam kegiatan pendaftaran selama ini, mulai dari permohonan seorang atau badan, diproses sampai dikeluarkan bukti haknya (sertifikat) dan dipelihara data pendaftarannya dalam buku tanah. ${ }^{17}$

${ }^{15}$ Hasil wawancara dengan anggota masyarakat di Kecamatan Galang, pada 9 Juli 2020.

${ }_{16}$ Maria Farida Naibaho, "Pengakuan Penguasaan Dan Pendudukan Tanah Tanpa Alas Hak Kepemilikan Yang Berakibat Sengketa: Studi Kasus Putusan Ma No. 2511k/Pdt/1995 Tanggal 09 September 1997',https://media.neliti.com/media/publications/14087-ID-pengakuan-penguasaan-dan-pendudukan-tanahtanpa-alas-hak-kepemilikan-yang-beraki.pdf diakses pada 5 Januari 2021

${ }^{17}$ Ibid. 
Meskipun Moch. Isnaini berpendapat bahwa sertifikat merupakan alat bukti awal dan bukan satu-satunya alat bukti mutlak yang pada dasarnya dapat digugurkan setiap saat oleh pihak lain yang terbukti lebih berwenang, ${ }^{18}$ namun sertifikat merupakan surat tanda bukti untuk hak atas tanah, hak pengelolaan, tanah wakaf, hak milik atas satuan rumah susun dan hak tanggungan yang masingmasing sudah dibukukan dalam buku tanah terkait. ${ }^{19}$ Dengan demikian, secara hukum sertifikat dapat digunakan sebagai alat bukti yang kuat dalam proses pembuktian terkait data fisik sebagaimana data yang tertera dalam surat ukur dan buku tanah sebagai jaminan bukti hak kepemilikan kepada seseorang sepanjang data fisik, data yuridis serta data administrasi yang tertera dalam dokumen pendaftaran tanah sesuai dengan fakta di lapangan. Berdasarkan sistem stelsel negative (pendaftaran negatif), suatu penetapan hak atas tanah tergantung pada data alas yang disampaikan oleh pemohon dalam rangka memenuhi persyaratannya. Penerbitan hak atas tanah menjadi cacat hukum bila data yang disampaikan oleh pemohon tidak sesuai dengan sebenarnya. ${ }^{20}$

Saat ini pihak Badan Pertanahan Nasional Batam tidak menerbitkan sertifikat terhadap kawasan Galang dikarenakan ber-status quo pada lahan tersebut, namun Badan Pertanahan Nasional Batam meletakkan Area Penggunanan Lain (APL) terhadap lahan yang ada di kawasan Galang. Menurut Badan Pertanahan Nasional (BPN) Kota Batam terkait status lahan di Galang yang menyangkut tumpang tindih kewenangan antara BP Batam dengan Pemko Batam sudah tidak ada permasalahan lagi karena jabatan Kepala Ex Officio BP Batam resmi dipimpin oleh Wali Kota Batam. Yang menjadi permasalahan saat ini adalah antara BP Batam dengan Kementerian Kehutanan wilayah Kepulauan Riau terkait penetapan status hutan pada lahan yang ada di Galang. Terhadap hak masyarakat yang memiliki alas hak di wilayah Galang akan menjadi prioritas namun tidak bisa diterbitkan sertifikat terhadap lahan tersebut. Menurut BPN Kota Batam memang banyak masyarakat maupun pengusaha mengajukan

\footnotetext{
18 Ibid

${ }^{19}$ Dapat dilihat pada Pasal 1 Angka 20 PP nomor 24 Tahun 1997 tentang Pendaftaran Tanah.

${ }^{20}$ Akibat Hukum Terhadap Sertipikat Ganda Yang Dikeluarkan Oleh BPN, https://Repository.Unsri. Ac.Id/17224/1/Rama_74201_02121001036_0001116501_0027068303_01_Front_Ref.Pdf, diakses pada 5 Januari 2021.
} 
penerbitan sertifikat dalam rangka meningkatkan status alas hak atas tanah mereka ke BPN Kota Batam namun karena masih ber-status quo terhadap lahan di Galang maka pihak BPN Kota Batam menolak untuk meningkatkan status tanah masyarakat maupun pengusaha di wilayah Galang. ${ }^{21}$

\section{Perlindungan Hukum Masyarakat Pemegang Alas Hak Tanah Berstatus Quo di Wilayah Pulau Galang}

Berdasarkan kronologi lahirnya alas hak atas tanah masyarakat di Pulau Galang dimulai sebelum dikeluarkannya Keputusan Presiden Nomor 28 Tahun 1992 dimana masyarakat yang ada di wilayah Pulau Galang memperoleh izin dari kepala desa untuk menggarap ataupun mengelola tanah di wilayah Galang baik dimanfaatan untuk berkebun maupun beternak. Setelah ada kantor Kecamatan di wilayah Galang, masyarakat Galang pun meningkatkan status tanah garapan mereka menjadi Alas Hak sesuai dengan prosedur dan ketentuan yang berlaku, dan Camat pun menerbitkan Alas Hak atas tanah mereka. ${ }^{22}$

Perkembangan perekonomian wilayah Galang pun mulai diminati pengusaha maupun investor dengan mendirikan berbagai bentuk usaha seperti dari segi sektor pariwisata, di bangun tempat-tempat wisata di wilayah Galang, yang mana perusahaan tersebut pun diberikan alas hak oleh Camat. Saat ini baik masyarakat maupun para pengusaha ingin meningkatkan status tanah mereka ke Badan Pertanahan Nasional kota Batam, namun BPN kota Batam tidak bisa mengeluarkan sertifikat ataupun peningkatan status atas lahan mereka karena masih dalam status quo. Sementara berdasarkan keterangan masyarakat Galang yang memegang alas hak, setiap tahun mereka membayar pajak berupa Pajak Bumi dan Bangunan (PBB) kepada Pemerintah Daerah atau dengan kata lain mereka ditagih pajak atas tanah tersebut setiap tahun. ${ }^{23}$

BPN Kota Batam menerangkan bahwa baik pihak BPN Kota Batam maupun BP Batam mengakui kebenaran terkait telah diberikannya hak untuk mengelola/menggarap tanah yang ada di Galang, namun hak tersebut tak bisa ditingkatkan status tanahnya, karena berdasarkan Keputusan Presiden Nomor 41

\footnotetext{
${ }^{21}$ Hasil wawancara dengan Kepala Bidang Penyelesaian Sengketa BPN Kota Batam pada 10 Juli 2020

${ }^{22}$ Hasil wawancara dengan masyarakat di Kecamatan Galang. Op. Cit.

${ }^{23}$ Ibid
} 
Tahun 1973 dijelaskan bahwa seluruh areal tanah yang terletak di Pulau Batam diserahkan dengan hak pengelolaan kepada Ketua Otoritas. Pengembangan Daerah Industri Pulau Batam yang sekarang disebut Badan Pengusahaan Batam (BP Batam), dengan kata lain, BP Batam sebagai instansi diberikan kewenangan oleh Negara untuk merencanakan, menggunakan, dan menyerahkan bagian dari tanah yang bersangkutan tersebut kepada pihak ketiga sesuai dengan ketentuan undang-undang yang berlaku. ${ }^{24}$

Berdasarkan rangkaian kondisi tersebut di atas, maka perlu dicari solusi yang terbaik bagi masyarakat terhadap perlindungan hak mereka atas tanah/lahan mereka di Galang. Prinsip perlindungan hukum bagi rakyat terhadap tindakan pemerintah bertumpu dan bersumber dari konsep tentang pengakuan dan perlindungan terhadap hak-hak asasi manusia yang diarahkan pada pembatasan-pembatasan dan peletakkan kewajiban pada masyarakat dan pemerintah. ${ }^{25}$

R. La Porta dalam Jurnal of Financial Economics menjelaskan bahwa bentuk perlindungan hukum yang diberikan oleh suatu negara memiliki dua sifat, yaitu bersifat pencegahan (prohibited) dan bersifat hukuman (sanction). Bentuk perlindungan hukum yang paling nyata adalah adanya institusi-institusi penegak hukum seperti pengadilan, kejaksaan, kepolisian, dan lembaga-lembaga penyelesaian sengketa di luar pengadilan (non-litigasi) lainnya. Perlindungan yang di maksud dengan bersifat pencegahan (prohibited) yaitu membuat peraturan, sedangkan perlindungan yang di maksud bersifat hukuman (sanction) yaitu menegakkan peraturan. Adapun tujuan serta cara pelaksanananya antara lain 1) membuat peraturan, yang bertujuan untuk memberikan hak dan kewajiban, b) menjamin hak-hak para subyek hukum; 2) menegakkan peraturan melalui: a) hukum administrasi negara yang berfungsi untuk mencegah terjadinya pelanggaran hak-hak dengan perizinan dan pengawasan; b) hukum pidana yang berfungsi untuk menanggulangi setiap pelanggaran terhadap peraturan perundang-undangan, dengan cara mengenakan sanksi hukum berupa

\footnotetext{
${ }^{24}$ Hasil wawancara dengan Kepala Bidang Penyelesaian Sengketa BPN Kota Batam. Op. Cit.

25 Adwin Tista, "Perlindungan Hukum Terhadap Pemegang Sertifikat Hak Atas Tanah Yang Mengalami Sengketa”, Jurnal LamLaj. Faculty of Law, Lambung Mangkurat University, Banjarmasin, 2019, hlm. 9.
} 
sansksi pidana dan hukuman; c) hukum perdata yang berfungsi untuk memulihkan hak dengan membayar kompensasi atau ganti kerugian. ${ }^{26}$

Pada perlindungan hukum dibutuhkan suatu wadah atau tempat dalam pelaksanaanya yang sering disebut dengan sarana perlindungan hukum. Sarana perlindungan hukum di bagi menjadi dua macam yaitu a) Sarana Perlindungan Hukum Preventif, yang mana subyek hukum diberikan kesempatan untuk mengajukan keberatan atau pendapatnya sebelum suatu keputusan pemerintah mendapat bentuk yang definitif. Tujuannya adalah mencegah terjadinya sengketa. Perlindungan hukum preventif sangat besar artinya bagi tindak pemerintahan yang didasarkan pada kebebasan bertindak karena dengan adanya perlindungan hukum yang preventif pemerintah terdorong untuk bersifat hati-hati dalam mengambil keputusan yang didasarkan pada diskresi. Di Indonesia belum ada pengaturan khusus mengenai perlindungan hukum preventif; b) Sarana Perlindungan Hukum Represif, Perlindungan hukum represif bertujuan untuk menyelesaikan sengketa. Penanganan perlindungan hukum oleh Pengadilan Umum dan Peradilan Administrasi di Indonesia termasuk kategori perlindungan hukum ini. Prinsip perlindungan hukum terhadap tindakan pemerintah bertumpu dan bersumber dari konsep tentang pengakuan dan perlindungan terhadap hak-hak asasi manusia karena menurut sejarah dari barat, lahirnya konsep-konsep tentang pengakuan dan perlindungan terhadap hak-hak asasi manusia diarahkan kepada pembatasanpembatasan dan peletakan kewajiban masyarakat dan pemerintah. Prinsip kedua yang mendasari perlindungan hukum terhadap tindak pemerintahan adalah prinsip negara hukum. Dikaitkan dengan pengakuan dan perlindungan terhadap hak-hak asasi manusia, pengakuan dan perlindungan terhadap hak-hak asasi manusia mendapat tempat utama dan dapat dikaitkan dengan tujuan dari negara hukum. ${ }^{27}$

Jika dikaitkan dengan fenomena hak atas tanah di Galang dengan teori perlindungan hukum di atas maka masyarakat pemegang alas hak tanah di Galang harus dilindungi haknya sebagaimana juga diamanatkan dalam Pasal 28 D ayat (1) Undang-Undang Dasar Negara Republik Indonesia Tahun 1945 bahwa "Setiap orang berhak atas pengakuan, jaminan, perlindungan dan kepastian 
hukum yang adil serta perlakuan yang sama di hadapan hukum". Ketentuan ini tentunya berlaku juga dalam bidang pertanahan.

Berdasarkan hasil wawancara dengan pihak BPN Kota Batam, upaya perlindungan hukum yang dilakukan pihak BPN adalah upaya pencegahan dengan tidak menerbitkan sertifikat hak atas tanah di Galang. Hal ini di samping karena perintah aturan perundang-undangan terkait juga pencegahan atas kerugian yang lebih besar bagi masyarakat. Namun demikian terhadap surat keterangan alas hak yang dimiliki baik oleh masyarakat maupun pengusaha yang ada di Galang tetap diakui sehingga apabila BP Batam ingin mengambil tanah/lahan di Galang yang sudah berstatus alas hak harus memberikan ganti kerugian terhadap tanamantanaman atau bangunan yang ada di atas tanah tersebut. ${ }^{28}$

Masyarakat maupun BP Batam hingga saat ini masih melakukan upayaupaya negosiasi atau musyawarah terkait status tanah di Galang, namun belum ada yang menempuh upaya melalui jalur litigasi atau pengadilan. Terkait posisi tawar masyarakat berdasar pada peruntukan, dimana jika lahan mereka diambil untuk kepentingan umum seperti pembangunan jalan, sekolah atau jembatan mungkin posisi harga bisa ditentukan oleh Pemerintah, namun jika peruntukan lahan mereka dikembangkan untuk investasi yang akan dikelola untuk pengusaha mereka meminta posisi tawar harga dari masyarakat sendiri. Masyarakat juga mengakui bahwa tanah/lahan yang ada di Galang memang bukan milik mereka tetapi bangunan dan tanaman-tananam yang ada diatasnya adalah hak mereka mereka menggarap sejak lama dan diberi izin secara legal untuk mengelola lahan tersebut. ${ }^{29}$

Mengenai tumpang tindih kewenangan perlu adanya kepastian hukum dan pengkajian dari pihak BP Batam maupun Kementerian Kehutanan di Kepulauan Riau. Salah satu konflik yang sering terjadi dan pada saat ini menjadi perhatian pemerintah adalah konflik kehutanan, konflik antara masyarakat sekitar hutan dengan perusahaan pemilih hak konsesi/pengelolaan hutan, konflik antara masyarakat sekitar hutan dengan dinas perhutanan terkait pemanfaatan kawasan hutan dan sebagainya. Masalah yang sering terjadi pada masyarakat sekitar hutan

\footnotetext{
${ }^{28}$ Hasil wawancara dengan Kepala Bidang Penyelesaian Sengketa BPN Kota Batam, Op. Cit.

${ }^{29}$ Hasil Wawancara dengan anggota Masyrakat Galang, Op. Cit.
} 
yang memicu konflik kehutanan antara lain kemiskinan, pengangguran, ketimpangan sosial dan pengelolaan/pemanfaatan kawasan hutan.

Kepastian hukum sangat diperlukan dalam penyelesaian sengketa pertanahan ini. Apabila tidak konsisten menjalankan peraturan dan memperlakukan seseorang atau masyrakat dengan tidak adil, maka peraturan hukum akan sangat membantu masyarakat karena hukum diterapkan secara pasti dan konsisten, meskipun masih ada yang merasa kurang adil, minimal dapat membantu warga masyarakat untuk belajar melindung diri sendiri dari konsekuensi buruk yang diakibatkan oleh perlakukan tidak adil. Jan Michiel Otto yang mengemukakan, bahwa untuk menciptakan kepastian hukumnya harus memenuhi syarat-syarat, yaitu 1) ada aturan hukum yang jelas dan konsisten; 2) instansi pemerintah menerapkan aturan hukum secara konsisten, tunduk dan taat terhadapnya; 3) masyarakat menyesuaikan perilaku mereka terhadap aturan hukum tersebut; 4) hakim-hakim yang mandiri, tidak berpihak dan harus menerapkan aturan hukum secara konsisten serta jeli sewaktu menyelesaikan sengketa hukum; 5) Putusan pengadilan secara konkret dilaksanakan. ${ }^{30}$

Undang-Undang Nomor 41 Tahun 1999 tentang Kehutanan memberikan kekuasaan kepada negara dalam hal ini Menteri Kehutanan untuk mengatur dan mengurus hutan, menetapkan status kawasan dan non kawasan, serta mengatur dan menetapkan hubungan hukum. Penetapan kawasan hutan dan bukan kawasan hutan/Areal Penggunaan Lain (APL) menjadi sangat penting terutama bagi masyarakat sekitar hutan karena penetapan kawasan hutan akan menimbulkan konsekuensi apa yang boleh dan apa yang tidak boleh dilakukan masyarakat di kawasan tersebut. Selain itu penetapan kawasan hutan juga akan berakibat pada timbulnya hak-hak di atas kawasan hutan, hak konservasi dan perlindungan, hak rehabilitasi dan reklamasi dan sebagainya. ${ }^{31}$

Sesuai dengan Peraturan Pemerintah Nomor 10 Tahun 2010 tentang Tata Cara Perubahan Peruntukan dan Fungsi Kawasan Hutan, status hutan konservasi itu harus diturunkan menjadi hutan lindung. Dari hutan lindung, statusnya

30 Adrian Sutedi, “Sertifikat Hak Atas Tanah”, Sinar Grafika, Jakarta, 2012, hlm. 26-27.

31 "Penetapan Kawasan Hutan" http://kejaritebo.go.id/2018/12/15/kedudukan-peta-penetapankawasan hutan-dalam-tindak pidanakehutanan/\#: :text=Lembaga $\% 20$ yang $\% 20$ diberikan $\% 20$ wewenang $\%$ 20untukdalam $\% 20$ pembuktian $\% 2$ Tindak $\% 20$ Pidana $\% 20$ Kehutanan. diakses pada 26 Juli 2020 
kemudian diturunkan menjadi hutan produksi. Selanjutnya diturunkan lagi menjadi hutan produksi yang bisa dikonversi. Barulah bisa menjadi areal penggunaan lain (APL) atau lahan yang bisa dialokasikan untuk kepentingan komersial atau investasi. Berlandaskan pada ketentuan peraturan tersebut maka penyelesaian lahan di wilayang Galang ini bisa terselesaikan dengan penurunan status lahan di Galang dari kawasan hutan menjadi Areal Penggunaan Lain (APL). BP Batam bisa melakukan koordinasi kepada pihak Kehutanan Provinsi Kepulauan Riau sehingga memperjelas status lahan di wilayah Galang dan pencabutan status quo terhadap lahan di Galang.

\section{Penutup}

Berpijak pada rumusan masalah serta hasil kajian, maka dapat disimpulkan bahwa Pertama, berdasarkan Keputusan Presiden Nomor 28 Tahun 1992 menetapkan penambahan Pulau Galang sebagai salah satu pulau yang termasuk ke dalam wilayah lingkungan kerja daerah industri Pulau Batam dan wilayah usaha Kawasan Berikat (Bonded Zone). Untuk daerah industri Pulau Batam diatur berdasarkan Keputusan Presiden Nomor 41 Tahun 1973 yang didalamnya juga mengatur terkait kewenangan hak pengeloaan atas tanah, dimana seluruh areal tanah yang terletak di Pulau Batam diserahkan dengan hak pengelolaan kepada Ketua Otorita Batam untuk merencanakan peruntukan dan penggunaan tanah untuk keperluan pelaksanaan tugasnya, menyerahkan bagian-bagian dari tanah tersebut kepada pihak ketiga dengan hak pakai, dan menerima uang pemasukan/ganti kerugian dan uang wajib tahunan. Ketentuan lebih lanjut terkait areal tanah diatur berdasarkan Keputusan Menteri Dalam Negeri Nomor 43 Tahun 1977. Meskipun kelembagaan Otorita Batam berubah menjadi Badan Pengusahaan Kawasan Perdagangan Bebas dan Pelabuhan Bebas Batam sebagaimana diatur dalam Peraturan Pemerintah Nomor 46 Tahun 2007 junto Peraturan Pemerintah Nomor 5 Tahun 2011, tetapi tidak mengubah status tanah yang hak pengelolaannya dimiliki oleh BP Batam.

Kedua, permasalahan tanah diawali dengan diterbitkannya Surat Keputusan Menteri Kehutanan Nomor 307/Kpts-II/1986 pada 29 September 1986 yang mana wilayah Galang masuk sebagai kawasan hutan, dan Surat Keputusan Nomor 
29 Tahun 2002 tentang Pengendalian Tata Guna Lahan Rempang dan Galang, yang akhirnya mengakibatkan kawasan tersebut menjadi ber-Status Quo. Sementara sebelum 1992 masyarakat yang berada di wilayah Pulau Galang telah memiliki alas hak atas lahan mereka yang diterbitkan oleh kecamatan setempat. Ketika masyarakat ingin meningkatkan status tanah dari alas hak menjadi sertifikat, BPN kota Batam tidak bisa mengeluarkan sertifikat ataupun meningkatan status atas tanah mereka dikarenakan masih ber-Status Quo. Terhadap permasalahan terssebut, masyarakat maupun BP Batam telah melakukan upaya negosiasi atau musryawarah dengan posisi tawar masyarakat dilandaskan pada peruntukan, dimana apabila lahan mereka diambil untuk kepentingan umum seperti pembangunan jalan, sekolah atau jembatan maka posisi harga ganti kerugian bisa ditentukan oleh Pemerintah, akan tetapi bila peruntukan tanah mereka digunakan untuk pengembangan investasi yang akan dikelola oleh pengusaha maka posisi tawar harga bisa ditentukan oleh masyarakat. Bentuk perlindungan lain yang dapat diberikan kepada masyarakat di Pulau Galang adalah dengan penurunan status dari kawasan hutan menjadi Areal Penggunaan Lain (APL)

\section{Daftar Pustaka}

\section{Buku}

Nurmandi, Ahmad, Menjaga Indonesia dari KEPRI (Peluang, Tantangan, \& Proil 19 Pulau Terdepan Indonesia di Kepulauan Riau, Badan Pengelola perbatasan Provinsi Kepulauan Riau, Tanjungpinang, 2012.

Sutedi, Adrian, Sertifikat Hak Atas Tanah, Sinar Grafika, Jakarta, 2012.

Tista, Adwin, "Perlindungan Hukum Terhadap Pemegang Sertifikat Hak Atas Tanah Yang Mengalami Sengketa", Jurnal LamLaj. Faculty of Law, Lambung Mangkurat University, Banjarmasin, 2019.

Utami, Febry Utami beserta Tim, Kecamatan Galang Dalam Angka, BPS Kota Batam, Batam, 2020.

\section{Jurnal dan Internet}

Anggraeny, Isdian, Akibat Hukum Insinkronisasi Pengaturan Bidang Pertanahan Di Kota Batam, Jurnal Mahasiswa Fakultas Hukum Universitas Brawijaya, 2014.

Hadiyati, Nur, "Memahami Problematikan Hak Pengelolaan Tanah Kota Batam Dalam Rangka Penetapan Batam Sebagai Kawasan Ekonomi Khusus", Jurnal Yurispruden, Volume 2 Nomor 1, Januari 2019. 
Naibaho,Maria Farida, "Pengakuan Penguasaan Dan Pendudukan Tanah Tanpa Alas Hak Kepemilikan Yang Berakibat Sengketa: Studi Kasus Putusan Ma No. 2511k/Pdt/1995 Tanggal 09 September 1997", https://media.neliti.com/media/publications/14087-ID-pengakuanpenguasaan-dan-pendudukan-tanah-tanpa-alas-hak-kepemilikan-yangberaki.pdf, diakses pada tanggal 14 Desember 2019.

"Pengadaan tanah bagi Pelaksanaan Pembangunan Untuk Kepentingan Umum" http:/ / docplayer.info/40543038-Bab-i-pendahuluan-tanah-merupakansarana-yang-sangat-penting-dalam-menunjang-pemenuhan-kebutuhanhidupnya-pembangunan-yang-meningkat-pesat.html, diakses pada tgl 5 Januari 2021.

"Pulau Galang dan Pulau Rempang Bakal Jadi Lokasi wisata" https: / / travel.tempo.co/read/1051777/pulau-galang-dan-pulaurempang-bakal-jadi-lokasi-wisata/full\&view $=$ ok, diakses tanggal 2 Februari 2021

"Akibat Hukum Terhadap Sertipikat Ganda Yang Dikeluarkan Oleh BPN" https: / Repository. Unsri.Ac.Id/17224/1/Rama_74201_02121001036_0001116501_0027068303 _01_Front_Ref.Pdf, diakses pada tgl 5 Januari 2021.

"Kedudukan Peta Penetapan Kawasan Hutan Dalam Tindak Pidana Kehutanan", http:/ / kejari-tebo.go.id/2018/12/15/kedudukan-peta-penetapankawasan-hutan-dalam-tindak-pidanakehutanan/\#: :text=Lembaga\%20yang\%20diberikan\%20wewenang\%20 untuk-dalam\%20pembuktian\%20Tindak\%20Pidana\%20Kehutanan. diakses pada tanggal 26 Juli 2020

"Kendala-Kendala Status Rempang-Galang", https://batampos.co.id/2018/ 03/22/ kendala-kendala-status-rempang-galang/, diakses pada tanggal 4 Januari 2021.

"Sejarah Batam", https://jdih.batam.go.id/?page_id=500, diakses pada tanggal 14 Desember 2019.

“Penetapan Kawasan Hutan"http://kejaritebo.go.id/2018/12/15/kedudukanpeta-penetapan-kawasan-hutan-dalam-tindak

pidanakehutanan/\#: :text=Lembaga \%20yang\%20diberikan\%20wewenan g\%20untukdalam\%20pembuktian\%2 Tindak\%20Pidana\%20Kehutanan. diakses pada tanggal 26 Juli 2020

\section{Peraturan Perundang-Undangan}

Undang-Undang Nomor 41 Tahun 1999 tentang Kehutanan, (Lembaran Negara Republik Indonesia Tahun 1999 Nomor 167, Tambahan Lembaran Negara RI Nomor 3888)

Undang-undang Nomor 53 Tahun 1999 tentang Pembentukan Kabupaten Pelalawan Kabupaten Rokan Hulu, Kabupaten Rokan Hilir, Kabupaten 
Siak, Kabupaten Karimun, Kabupaten Natuna, Kabupaten Kuantan Singingi, Dan Kota Batam, (Lembaran Negara Republik Indonesia Tahun 1999 Nomor 151, Tambahan Lembaran Negara RI Nomor, Tambahan Lembaran Negara RI Nomor 3902)

Undang-Undang Nomor 13 Tahun 2000 tentang Perubahan Atas Undang-Undang Nomor 53 Tahun 1999, (Lembaran Negara Republik Indonesia Tahun 2000 Nomor 80, Tambahan Lembaran Negara RI Nomor 3968).

Undang-Undang Nomor 25 Tahun 2002 tentang Pembentukan Provinsi Kepulauan Riau.

Peraturan Pemerintah Nomor 22 Tahun 1986 tentang Kawasan Berikat (Bonded Zone), (Lembaran Negara Tahun 1986 Nomor 30, Tambahan Lembaran Negara Nomor 3334).

Peraturan Pemerintah Nomor 24 Tahun 1997 tentang Pendaftaran Tanah, (Lembaran Negara Nomor 59 Tahun 1997)

Peraturan Pemerintah Nomor 46 Tahun 2007 tentang Kawasan Perdagangan Bebas Dan Pelabuhan Bebas Batam.

Pemerintah Nomor 10 Tahun 2010 tentang Tata Cara Perubahan Peruntukan dan Fungsi Kawasan Hutan, (Lembaran Negara Republik Indonesia Tahun 2010 Nomor 15, Tambahan Lembaran Negara RI Nomor 5097).

Peraturan Pemerintah Nomor 5 Tahun 2011 tentang Perubahan Atas Peraturan Pemerintah Nomor 46 Tahun 2007, Lembaran Negara Republik Indonesia Tahun 2011 Nomor 16, Tambahan Lembaran Negara RI Nomor 5195

Keputusan Presiden Nomor 41 Tahun 1973 tentang Daerah Industri Pulau Batam

Keputusan Presiden Nomor 28 Tahun 1992 tentang Penambahan Wilayah Lingkungan Kerja Daerah Industri Pulau Batam Dan Penetapannya Sebagai Wilayah Usaha Kawasan Berikat (Bonded Zone)

Keputusan Nomor 29 tahun 2002 tentang Pengendalian Tata Guna Lahan Rempang dan Galang

Keputusan Menteri Dalam Negeri Nomor 43 Tahun 1977 tentang Pengelolaan Dan Penggunaan Tanah Di Daerah Industri Pulau Batam

Keputusan Kehutanan Republik Indonesia Nomor SK. 463/Menhut-II/2013 tentang Perubahan Peruntukan Kawasan Hutan Menjadi Bukan Kawasan Hutan Seluas +/- 124.775 (Seratus Dua Puluh Empat Tujuh Ratus Tujuh Puluh Lima) Hektar, Perubahan Fungsi Kawasan Hutan Seluar + /- 86.663 (Delapan Puluh Enam Ribu Enam Ratus Enam Puluh Tiga) Hektar Dan Perubahan Bukan Kawasan Hutan Menjadi Kawasan Hutan Seluas +/1.834 (Seribu Delapan Ratus Tiga Puluh Empat) Hektar Di Provinsi Kepulauan Riau. 